\title{
BRINE SHRIMP TERATOGENIC SCREENING TEST ON SOME SELECTED PLANTS
}

\author{
METI WIDIYA LESTARI ${ }^{1,4 *}$, IRDA FIDRIANNY ${ }^{2}$, AYDA T YUSUF ${ }^{3}$, ANDREANUS A SOEMARDJI ${ }^{1}$
}

${ }^{1}$ Pharmacology-Clinical Pharmacy Research Group, School of Pharmacy, Bandung Institute of Technology, Bandung, Indonesia. ${ }^{2}$ Pharmaceutical Biology Research Group, School of Pharmacy, Bandung Institute of Technology, Bandung, Indonesia. ${ }^{3}$ Biomedic of Animal Physiology and Development Research Group, School of Life Science and Technology, Bandung Institute of Technology, Indonesia. ${ }^{4}$ Department of Midwives, Tasikmalaya Polytechnic of Health Ministry of Health, Tasikmalaya, Bandung, Indonesia. Email: meti.weel@gmail.com

Received: 03 April 2017; Revised and Accepted: 24 April 2017

\section{ABSTRACT}

Objectives: The aims of this research were to analyze teratogenic properties on some selected plants which often used for woman's health were pomegranate (Punica granatum L.) pericarp, coriander (Coriandrum sativum L.) seeds, liman (Elephantopus scaber L.) leaves, fennel (Foeniculum vulgare M.) seeds, and kaempferia (Kaempferia galanga L.) rhizomes using brine shrimp teratogenic screening test (BSTST) method.

Methods: Artemia cysts were hatched into first stage nauplii then taken and put into seawater medium which contain test substance and kept alive until the second stage, third stage, and fourth stage and then observed number of deaths, morphological abnormalities, body length, and retarded of development for each stage.

Results: Hatchability of cysts in fennel seeds compared extracts 1 and $0.5 \mathrm{mg} / \mathrm{ml}$, coriander seeds extract $1 \mathrm{mg} / \mathrm{ml}$, pomegranate rinds extract $6 \mathrm{mg} / \mathrm{ml}$, and liman leaves extracts 6,3 , and $1.5 \mathrm{mg} / \mathrm{ml}$ were significantly different to control $(\mathrm{p}<0.05)$. Survival nauplii in fennel seeds extracts 1 and $0.5 \mathrm{mg} / \mathrm{ml}$ and liman leaves extracts 6 and $3 \mathrm{mg} / \mathrm{ml}$ were significantly different to control $(\mathrm{p}<0.05)$. The morphological abnormalities were exposed on coriander seeds extract $1 \mathrm{mg} / \mathrm{ml}$, liman leaves extract $6 \mathrm{mg} / \mathrm{ml}$, and pomegranate rinds extract $3 \mathrm{mg} / \mathrm{ml}$. Nauplii with retarded development were presented on fennel seeds extracts 1 and $0.5 \mathrm{mg} / \mathrm{ml}$, coriander seeds extracts 1 and $0.25 \mathrm{mg} / \mathrm{ml}$, pomegranate rinds extracts 6,3 , and $1.5 \mathrm{mg} / \mathrm{ml}$, and liman leaves extracts 3 and $1.5 \mathrm{mg} / \mathrm{ml}$. Nauplii body length on plants extract showed no significantly difference compared to control.

Conclusion: Based on BSTST, fennel seed and pomegranate rind extracts had no teratogenic effect, kaempferia rhizomes act as larvicide its analog in mamalia as embryo lethal, while coriander seeds and liman leaves extracts potentially had teratogenic properties.

Keywords: Brine shrimp test, Teratogen, Fennel, Coriander, Pomegranate, Liman, Kaempferia.

(C) 2017 The Authors. Published by Innovare Academic Sciences Pvt Ltd. This is an open access article under the CC BY license (http://creativecommons. org/licenses/by/4. 0/) DOI: http://dx.doi.org/10.22159/ajpcr.2017.v10i8.18861

\section{INTRODUCTION}

The use of traditional medicine has been known long time, for curing and also as preventive and health care. Around $30.4 \%$ households in Indonesia used traditional health services, and $49.0 \%$ of them used jamu which contained 1-5 of the crude drug [1]. The use and knowledge regarding traditional medicine are very diverse, and some of traditional medicines were used by women to cure diseases and health care.

Pomegranate (Punica granatum L.), coriander (Coriandrum sativum L.), liman (Elephantopus scaber L.), fennel (Foeniculum vulgare M.), and kaempferia (Kaempferia galanga L.) were plants that often used as traditional medicine for women's health care, such as during pregnancy, menstrual disorders, aphrodisiacs, contraceptives, body treatments, and postnatal [2-4]. Several studies revealed that these plants also had antifertility, anti-implantation [5] and inhibit proliferation effects [6-9]. The use of these five plants by women, especially, during conception and pregnancy was feared could affect the growth and development of embryo or fetus; therefore, it is very necessary for testing teratogenic on these plants.

Teratogenicity test is a test designed to observe the special effects of a substance on a fetus that includes death, morphological abnormality, retarded development, and functional disorders [10]. Some teratogenic testings have been developed lately in hopes of finding a reliable method, rapid testing, as well as cost [11]. One teratogenic testing method, namely, brine shrimp test has been developed, which used Artemia salina L. belongs to crustacean [12].
Teratogenic test using brine shrimp has been conducted by Kerster and Schaeffer [13], Sleet and Brendel [14] then developed and modified in the previous research [12]. This method is an alternative method for screening teratogenic. It does not require complex skills, inexpensive and can provide rapid result [12-14], therefore, this method can be selected to evaluate teratogenic effect on five medicinal plants that are often used by the public for women's health.

The purposes of this study were to analyze any teratogenic properties on extracts of fennel seeds, coriander seeds, liman leaves, pomegranate pericarp, and kaempferia rhizomes as a medicinal plant for women's health and are expected to reveal useful information for safety usages of those plants during pregnancy.

\section{MATERIALS AND METHODS}

\section{Materials}

Animals were Artemia salina L. cysts which were produced by Ocean Star International Inc., Utah, USA. Pomegranate ( $P$. granatum L.) pericarp, coriander (C. sativum L.) seeds, liman (E. scaber L.) leaves, fennel ( $F$. vulgare M.) seeds, and kaempferia (K. galanga L.) rhizomes were collected from Lembang, West Java, Indonesia.

\section{Sample preparation}

Pomegranate ( $P$. granatum L.), coriander (C. sativum L.), liman (E. scaber L.), fennel (F. vulgare M.), and kaempferia (K. galanga L.) were determined at Herbarium of School of Life Sciences and Technology, Bandung Institute of Technology. All samples were thoroughly washed with tap water, sorted while wet, cut, dried, and grinded into powder. 
Crude drug was extracted using 96\% ethanol by reflux method and evaporated by rotary evaporator. Each extract was prepared in three different concentrations. The fennel seed and coriander seed were 1, 0.5 and $0.25 \mathrm{mg} / \mathrm{ml}$, whereas liman leaves, pomegranate pericarp, and kaempferia rhizomes were 6,3 , and $1.5 \mathrm{mg} / \mathrm{ml}$.

\section{Hatching ability}

As much as 10 cysts were hatched in vial which contain $5 \mathrm{ml}$ of seawater (with salinity $9 \mathrm{mg} / \mathrm{ml}$ ) and extract, at temperature of $25-28^{\circ} \mathrm{C}$, aerated and illuminated. After $36 \mathrm{hrs}$, hatching ability of cysts in each group were analyzed and the replication was performed 5 times.

Death of nauplii, morphological abnormalities, retarded development, and body length

As much as $1 \mathrm{~g}$ cysts were hatched in a beaker which contain $400 \mathrm{ml}$ of seawater (salinity $9 \mathrm{mg} / \mathrm{ml}$ ) and test substance, at temperature of $25-28^{\circ} \mathrm{C}$, aerated and illuminated. After hatching, the first stage of Artemia nauplii (1-2 hrs after hatching) was sampled out then tested in each group which contains seawater and extract. In Group 1, nauplii were keep alive until second stage, Group 2 keep alive until third stage, and Group 3 keep alive until fourth stage. Nauplii that were taken from each group then put into Bouin solution for fixating. Observation was carried out using a microscope with a magnification of 100 times, with 5 times replication, included death of nauplii, morphological abnormalities, retarded development, and body length of nauplii.

\section{RESULTS}

\section{Hatching ability of cyst}

A number of cysts were hatched in medium seawater which contain extract with various concentrations in each group. Cysts cannot hatched in all concentrations of kaempferia rhizome extracts and liman leaves extract with a dose of $6 \mathrm{mg} / \mathrm{ml}$. Hatching ability of cyst in fennel seeds extracts 1 and $0.5 \mathrm{mg} / \mathrm{ml}$, coriander seed extract $1 \mathrm{mg} / \mathrm{ml}$, and pomegranate pericarp extract $6 \mathrm{mg} / \mathrm{ml}$ were significantly different compared to the control group $(\mathrm{p}<0.05)$ and can be seen in Fig. 1.

The results also showed relationship between the concentration and the hatching ability of cysts, where a high concentration tends to depress hatching ability of cyst larger than low concentration.

\section{Death of nauplii}

It can be seen in Table 1, Nauplii in all concentrations of kaempferia rhizomes extract cannot survive. All nauplii died since the second stage (19 hrs). At the second stage, liman leaves $6 \mathrm{mg} / \mathrm{ml}$ gave the highest mortality of nauplii. Kaempferia rhizomes extract and liman leaves extract had significantly different compared to control group $(\mathrm{p}<0.05)$.

At the third stage, all of nauplii were dead in liman leaves extract $6 \mathrm{mg} / \mathrm{ml}$, while fennel seeds extracts 1 and $0.5 \mathrm{mg} / \mathrm{ml}$ presented significantly different compared to control group $(\mathrm{p}<0.05)$

At the fourth stage, $28 \%$ of nauplii died in control group and $100 \%$ died in fennel seeds extracts at all concentrations, pomegranate pericarp extract $3 \mathrm{mg} / \mathrm{ml}$, and liman leaves extracts 6 and $1.5 \mathrm{mg} / \mathrm{ml}$, while in the other groups nauplii could survive only $<10 \%$.

\section{Morphological abnormality}

Observations have been carried out on all groups both the control and extract to see morphological abnormalities. Each group was done 5 times replications. At the second stage, there was morphological abnormality in liman leaves extract $6 \mathrm{mg} / \mathrm{ml}$, while the nauplii without antenna and there were arches at the thoracopod body part (Fig. 2).

The third stage found two morphological abnormalities, which were nauplii with shorter bilateral gnatobasten in coriander seeds extract $0.5 \mathrm{mg} / \mathrm{ml}$ and nauplii with an arch in the lateral portion of the tail in pomegranate pericarp extract $3 \mathrm{mg} / \mathrm{ml}$ (Fig. 3 ).

\section{Retarded development}

At the second stage, liman leaves extract $3 \mathrm{mg} / \mathrm{ml}$ expressed the greatest number of nauplii with retarded development (7.14\%). At the third stage, the highest retarded development of nauplii was given by fennel seeds extract $1 \mathrm{mg} / \mathrm{ml}$, whereas at the fourth stage only coriander seed extract $0.5 \mathrm{mg} / \mathrm{ml}$ showed nauplii with retarded development (Table 2).

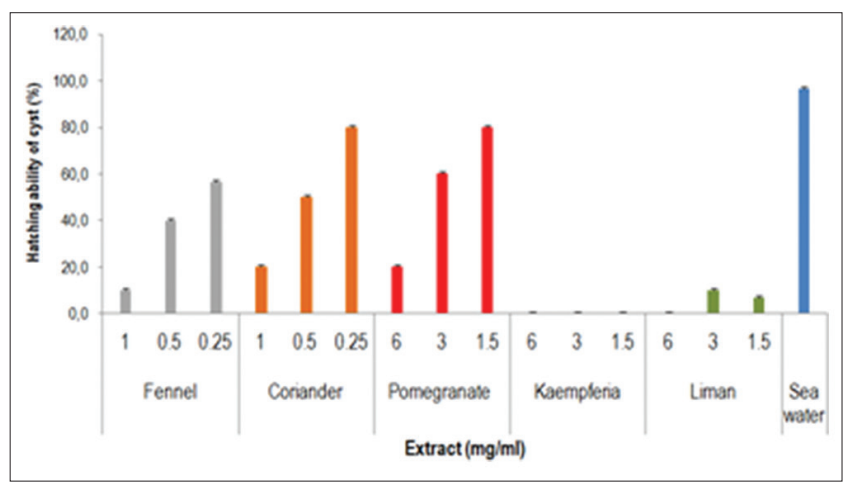

Fig. 1: Hatching ability of cyst in extracts

Table 1: Death of nauplii in extracts

\begin{tabular}{llll}
\hline Sample & Death nauplii (\%) & & \\
\cline { 2 - 4 } & Second stage & Third stage & Fourth stage \\
\hline Seawater & $0.00 \pm 0.00$ & $0.00 \pm 0.00$ & $28.00 \pm 2.31$ \\
Methotrexate & $0.00 \pm 0.00$ & $0.00 \pm 0.00$ & $100.00 \pm 0.00^{*}$ \\
Fennel $1 \mathrm{mg} / \mathrm{ml}$ & $50.00 \pm 1.53$ & $96.00 \pm 0.58^{*}$ & $100.00 \pm 0.00^{*}$ \\
Fennel $0.5 \mathrm{mg} / \mathrm{ml}$ & $46.00 \pm 1.00$ & $78.00 \pm 3.21^{*}$ & $100.00 \pm 0.00^{*}$ \\
Fennel $0.25 \mathrm{mg} / \mathrm{ml}$ & $12.00 \pm 0.00$ & $82.00 \pm 3.61$ & $100.00 \pm 0.00^{*}$ \\
Coriander $1 \mathrm{mg} / \mathrm{ml}$ & $40.00 \pm 0.00$ & $40.00 \pm 0.00$ & $98.00 \pm 0.58^{*}$ \\
Coriander $0.5 \mathrm{mg} / \mathrm{ml}$ & $40.00 \pm 0.00$ & $24.00 \pm 0.00$ & $92.00 \pm 0.58^{*}$ \\
Coriander $0.25 \mathrm{mg} / \mathrm{ml}$ & $0.00 \pm 0.00$ & $4.00 \pm 0.00$ & $90.00 \pm 1.53$ \\
Pomegranate $6 \mathrm{mg} / \mathrm{ml}$ & $26.00 \pm 1.15$ & $76.00 \pm 5.77$ & $92.00 \pm 2.31^{*}$ \\
Pomegranate $3 \mathrm{mg} / \mathrm{ml}$ & $2.00 \pm 0.00$ & $14.00 \pm 4.04$ & $100.00 \pm 0.00^{*}$ \\
Pomegranate $1.5 \mathrm{mg} / \mathrm{ml}$ & $2.00 \pm 0.58$ & $6.00 \pm 1.73$ & $98.00 \pm 0.58^{*}$ \\
Kaempferia $6 \mathrm{mg} / \mathrm{ml}$ & $100.00 \pm 0.00^{*}$ & $100.00 \pm 0.00$ & $100.00 \pm 0.00^{*}$ \\
Kaempferia $3 \mathrm{mg} / \mathrm{ml}$ & $100.00 \pm 0.00^{*}$ & $100.00 \pm 0.00^{*}$ & $100.00 \pm 0.00^{*}$ \\
Kaempferia $1.5 \mathrm{mg} / \mathrm{ml}$ & $100.00 \pm 0.00^{*}$ & $100.00 \pm 0.00^{*}$ & $100.00 \pm 0.00^{*}$ \\
Liman $6 \mathrm{mg} / \mathrm{ml}$ & $96.00 \pm 0.58^{*}$ & $100.00 \pm 0.00^{*}$ & $100.00 \pm 0.00^{*}$ \\
Liman $3 \mathrm{mg} / \mathrm{ml}$ & $72.00 \pm 5.03^{*}$ & $80.00 \pm 5.77$ & $98.00 \pm 0.58^{*}$ \\
Liman $1.5 \mathrm{mg} / \mathrm{ml}$ & $64.00 \pm 3.46$ & $78.00 \pm 5.51$ & $100.00 \pm 0.00^{*}$ \\
\hline
\end{tabular}

Replication is performed 5 times, $n=50$ * Significantly different compared to control $(\mathrm{p}<0.05)$ 


\section{Body length}

In Table 3, it can be seen that the shortest body length of nauplii was given by liman leaves extract $6 \mathrm{mg} / \mathrm{ml}$ at the second stage while the third stage shown by fennel seeds extract $1 \mathrm{mg} / \mathrm{ml}$ which was significant different to the other groups. At the fourth stage, pomegranate pericarp extract $1.5 \mathrm{mg} / \mathrm{ml}$ represented the shortest body length although the difference was not statistically significant.

\section{DISCUSSION}

In the present study, Artemia cysts hatched within 24-36 hrs. It was similar to research by Sorgeloos et al. [15] and Lestari et al. [12]. It can also be seen that the relationship between concentration and number of cysts hatch, where in higher concentration, could depress the hatchability of cyst and give the lower number of cyst.

In medium which contained extract, only around 2-8\% nauplii still lived at the fourth stage. In some extracts such as liman leaves extract and pomegranate pericarp extract, it can due to increasing in density, while extract which contain oil such as coriander seed extract and

Table 2: The retarded development of nauplii in extracts

\begin{tabular}{llll}
\hline Sample & \multicolumn{2}{l}{ Retarded development (\%) } \\
\cline { 2 - 4 } & $\begin{array}{l}\text { Second } \\
\text { Stage }\end{array}$ & Third & Fourth \\
& - & - & Stage \\
\hline Seawater & $3.33 \pm 0.58$ & $20.00 \pm 1.73$ & - \\
Methotrexate $15 \mu \mathrm{g} / \mathrm{ml}$ & - & $50.00 \pm 0.58$ & - \\
Fennel $1 \mathrm{mg} / \mathrm{ml}$ & $3.70 \pm 0.57$ & - & - \\
Fennel $0.5 \mathrm{mg} / \mathrm{ml}$ & - & - & - \\
Fennel $0.25 \mathrm{mg} / \mathrm{ml}$ & $3.33 \pm 0.57$ & $16.67 \pm 2.89$ & - \\
Coriander $1 \mathrm{mg} / \mathrm{ml}$ & - & - & $4.76 \pm 0.58$ \\
Coriander $0.5 \mathrm{mg} / \mathrm{ml}$ & $3.33 \pm 0.57$ & $3.33 \pm 0.58$ & - \\
Coriander $0.25 \mathrm{mg} / \mathrm{ml}$ & & $10.00 \pm 0.58$ & - \\
Pomegranate $6 \mathrm{mg} / \mathrm{ml}$ & $3.45 \pm 0.57$ & $13.04 \pm 0.00$ & - \\
Pomegranate $3 \mathrm{mg} / \mathrm{ml}$ & - & $18.52 \pm 2.89$ & - \\
Pomegranate $1.5 \mathrm{mg} / \mathrm{ml}$ & - & - & - \\
Kaempferia $6 \mathrm{mg} / \mathrm{ml}$ & - & - & - \\
Kaempferia $3 \mathrm{mg} / \mathrm{ml}$ & - & - & - \\
Kaempferia $1.5 \mathrm{mg} / \mathrm{ml}$ & - & - & - \\
Liman $6 \mathrm{mg} / \mathrm{ml}$ & - & $10.00 \pm 0.58$ & - \\
Liman $3 \mathrm{mg} / \mathrm{ml}$ & $7.14 \pm 0.57 *$ & $36.36 \pm 1.53$ & - \\
Liman $1.5 \mathrm{mg} / \mathrm{ml}$ & - & &
\end{tabular}

Replication is performed 5 times, $\mathrm{n}=50$. ${ }^{*}$ Significantly different compared to control $(\mathrm{p}<0.05)$ kaempferia rhizomes extract, it can also be caused by increasing level in turbidity. Density and level of turbidity of sample in medium can directly affect survival of nauplii. pH below 5 or higher than 10 could kill Artemia [12,15]. All of nauplii in kaempferia rhizomes extracts were died since the second stage, so there was no nauplii progressed to the further stage. Hence, it can be predicted that kaempferia rhizome extract had larvicide effect for Artemia's nauplii its analog in mamalia as embryo lethal. It was similar to the previous research which claimed that the kaempferia rhizome extract gave larvicide properties for Culex quinquefasciatus [16] and also Aedes aegypti [17].

Morphological abnormalities which were found in this study were the arch at the thoracopod body part, shorter gnatobasten, and antenna did not grow. In adult Artemia, there are 11 pairs of thoracopod which acts as a means of motion, gills, and foragers [18]. Abnormalities in any part of the nauplii's body that would later become thoracopod may cause disturbances in the respiratory system, transport, digestion, and reproduction in adult Artemia. Gnatobasten on Artemia acts as a means of motion [18], so the shorter gnatobasten might cause disruption of transportation in nauplii. Antenna on adult Artemia serves as a sensory, and on male Artemia, its act as a hook tool when copulation [18];
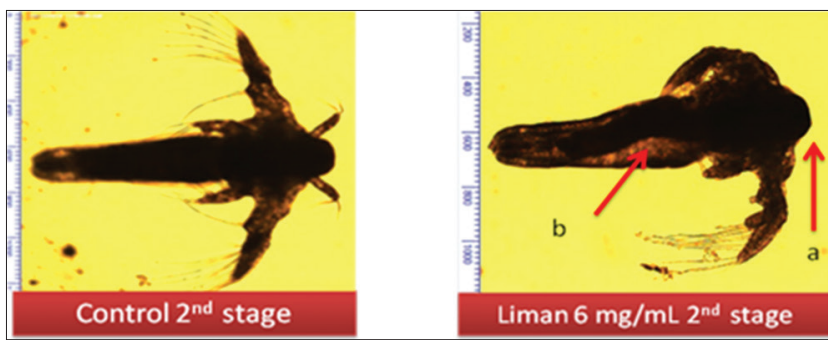

Fig. 2: Morphological abnormality of nauplii at the second stage. (a) Antenna did not grow, (b) arch at the thoracopod body part

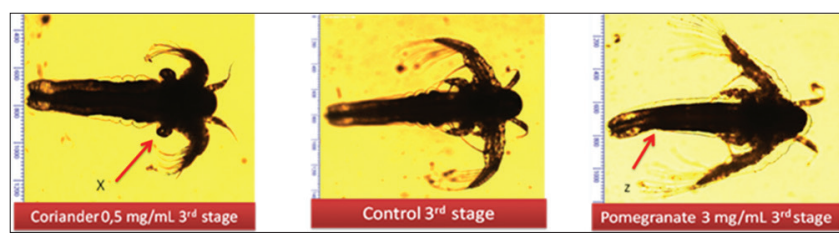

Fig. 3: Morphological abnormality of nauplii at the third stage. (x) Shorter gnatobasten, (z) arch at lateral of the tail

Table 3: Body length of nauplii in extracts

\begin{tabular}{llll}
\hline Sample & Body length $(\mu \mathrm{m})$ & & Fourth stage \\
\cline { 2 - 4 } & Second stage & Third stage & $1505.64 \pm 90.06$ \\
\hline Seawater & $896.70 \pm 90.86$ & $1074.00 \pm 70.27$ & - \\
Methotrexate $15 \mu \mathrm{g} / \mathrm{ml}$ & $872.76 \pm 78.73$ & $1019.84 \pm 38.15$ & - \\
Fennel $1 \mathrm{mg} / \mathrm{ml}$ & $887.96 \pm 60.10$ & $964.87 \pm 235.76$ & - \\
Fennel $0.5 \mathrm{mg} / \mathrm{ml}$ & $890.31 \pm 59.53$ & $1002.99 \pm 104.95$ & - \\
Fennel $0.25 \mathrm{mg} / \mathrm{ml}$ & $943.94 \pm 97.47$ & $1060.92 \pm 85.70$ & $2030.00 \pm 0.00$ \\
Coriander $1 \mathrm{mg} / \mathrm{ml}$ & $860.70 \pm 96.46$ & $1035.59 \pm 24.46$ & $1735.97 \pm 494.99$ \\
Coriander $0.5 \mathrm{mg} / \mathrm{ml}$ & $876.86 \pm 68.75$ & $1047.50 \pm 81.99$ & $1431.85 \pm 13.56$ \\
Coriander $0.25 \mathrm{mg} / \mathrm{ml}$ & $902.70 \pm 65.89$ & $1097.28 \pm 43.24$ & $2179.04 \pm 0.00$ \\
Pomegranate $6 \mathrm{mg} / \mathrm{ml}$ & $851.54 \pm 159.93$ & $1232.03 \pm 0.00$ & - \\
Pomegranate $3 \mathrm{mg} / \mathrm{ml}$ & $868.41 \pm 129.41$ & $1008.99 \pm 108.23$ & $1344.02 \pm 0.00$ \\
Pomegranate $1.5 \mathrm{mg} / \mathrm{ml}$ & $868.57 \pm 116.63$ & $1104.40 \pm 159.38$ & - \\
Kaempferia $6 \mathrm{mg} / \mathrm{ml}$ & - & - & - \\
Kaempferia $3 \mathrm{mg} / \mathrm{ml}$ & - & - & - \\
Kaempferia $1.5 \mathrm{mg} / \mathrm{ml}$ & - & - & - \\
Liman $6 \mathrm{mg} / \mathrm{ml}$ & $789.27 \pm 99.87$ & - & $1353.65 \pm 0.00$ \\
Liman $3 \mathrm{mg} / \mathrm{ml}$ & $896.95 \pm 114.21$ & $1183.84 \pm 0.00$ & - \\
Liman $1.5 \mathrm{mg} / \mathrm{ml}$ & $917.19 \pm 127.49$ & $1123.00 \pm 227.70$ & \\
\hline
\end{tabular}

Replication is performed 5 times, $\mathrm{n}=50$ 
therefore, the loss of antenna can cause disruption of reproductive system and sensors on adult Artemia.

In the present study, it could be seen the affect of extract to development of nauplii although it was not statistically significant. The retarded development that be found were retarded development of nauplii which should be in advance stage, but it still in below stage; however, it was not linear with concentration. The higher concentration did not always give increasing in retarded development. The previous research [12] showed that developmental delay disorder can be caused also by differences in time in hatch of cysts.

Although it was not significant different body length between nauplii in seawater and nauplii in extract, the higher concentration of extract gave shorter body length of nauplii, and the higher concentration showed more different body length compared to control. Some previous studies [12-14] stated that the differences in body length of nauplii indicated growth disturbance on Artemia.

Based on the brine shrimp teratogenic screening test which used five parameters and tested five plants extracts, it could be seen that liman leaves extract and coriander seeds extract complied almost all of parameters. Fennel seeds extract and pomegranate pericarp extract complied a few parameters, whereas kaempferia rhizomes extract just stop at one parameter only. Therefore, liman leaves extract and coriander seeds extract the most likely to have teratogenic effect.

\section{CONCLUSION}

Liman leaves extract and coriander seeds extract potentially had teratogenic properties. Fennel seeds extract and pomegranate pericarp extract had no teratogenic effect, while kaempferia rhizomes extract acts as larvicide its analog with embryo lethal in mammal.

\section{REFERENCES}

1. Agency for Health Research and Development. Basic Health Research Report. Jakarta: Ministry of Health of Indonesia; 2010.

2. Perry LM. Medicinal Plant of East and Southeast Asia. London: The MIT Press; 1980.

3. Lestari MW, Soemardji AA, Fidrianny I. Review of traditional use, pharmacological effects and toxicity of medicinal plants for women's health in Indonesia. Asian J Pharm Clin Res 2016;9(1):32-7.

4. Mahajan DC, Satyapal US, Tatke PA, Naharwar VA. Evaluation of
Punica granatum fruit peels extracts for its free radical scavenging and anti-inflammatory activity. Int J Pharm Pharm Sci 2015;7(7):222-5.

5. Al-Said MS, Al-Khamis KI, Islam MW, Parmar NS, Tariq M, Ageel AM. Post-coital antifertility activity of the seeds of Coriandrum sativum in rats. J Ethnopharmacol 1987;21(2):165-73.

6. Tang EL, Rajarajeswaran J, Fung SY, Kanthimathi MS. Antioxidant activity of Coriandrum sativum and protection against DNA damage and cancer cell migration. BMC Complement Altern Med 2013;13:347.

7. Huang CC, Lo CP, Chiu CY, Shyur LF. Deoxyelephantopin, a novel multifunctional agent, suppresses mammary tumour growth and lung metastasis and doubles survival time in mice. Br J Pharmacol 2010;159(4):856-71.

8. Umar MI, Asmawi MZ, Sadikun A, Majid AM, Al-Suede FS, Hassan LE, et al. Ethyl-p-methoxycinnamate isolated from Kaempferia galanga inhibits inflammation by suppressing interleukin-1, tumor necrosis factor-a, and angiogenesis by blocking endothelial functions. Clinics (Sao Paulo) 2014;69(2):134-44

9. Nithya TG, Sumalatha D. Evaluation of in vitro anti-oxidant and anticancer activity of Coriandrum sativum against human colon cancer ht-29 cell lines. Int J Pharm Pharm Sci 2014;6(2):421-4.

10. Wilson JG, Fraser FC. Handbook of Teratology: General Principles and Etiology. New York: Plenum Press; 1977. p. 49-72.

11. Schumann J. Teratogen screening state of the art. Avicenna J Med Biotech 2010;2(3):115-21.

12. Lestari MW, Soemardji AA, Fidrianny I, Yusuf AT. The capability of brine shrimp test as a teratogenicity screening system. Asian J Pharm Clin Res 2017;10(3):454-7.

13. Kerster HW, Schaeffer DJ. Brine shrimp (Artemia salina) nauplii as a teratogen test system. Ecotoxicol Environ Saf 1983;7(3):342-9.

14. Sleet RB, Brendel K. Homogeneous populations of Artemia nauplii and their potential use for in vitro testing in developmental toxicology. Teratog Carcinog Mutagen 1985;5(1):41-54.

15. Sorgeloos P, Remiche-Van Der Wielen C, Persoone G. The use of Artemia nauplii for toxicity tests - A critical analysis. Ecotoxicol Environ Saf 1978;2(3-4):249-55.

16. Choochote W, Kanjanapothi D, Panthong A, Taesotikul T, Jitpakdi A, Chaithong U, et al. Larvicidal, adulticidal and repellent effects of Kaempferia galanga. Southeast Asian J Trop Med Public Health 1999;30(3):470-6.

17. Satoto TB, Maniam S, Ganesen K, Ernaningsih. Larvicidal effect of ether and chloroform extract of Kaempferia galanga against the larvae of Aedes aegypti (Diptera: Culicidae). Int J Pharmacogn Phytochem Res 2013;5(2):96-100.

18. Stappen GV. Manual of the Production and Use of life Food for Aquaculture. Belgium: Laboratory of Aquaculture and Artemia Reference Center; 1996. 